\title{
KEMANDIRIAN PEREMPUAN MELALUI KETERAMPILAN MENJAHIT
}

Berlianti $^{1)}$, Mastauli Siregar ${ }^{1)}$,

1) Staf pengajar Prodi Kesejahteraan Sosial FISIP USU

\begin{abstract}
ABSTRAK
Wirausaha jasa menjahit pakaian masih menjanjikan. Meski sekarang sudah banyak produksi pakaian jadi, tetapi jasa jahitan tetap dibutuhkan konsumen. Karena ada beberapa risiko pembelian pakaian jadi yang biasanya diterima oleh pembeli. Tidak semua pakaian jadi pas dikenakan oleh konsumen. Terutama bagi orang-orang memiliki postur tubuh berbeda dengan standar orang pada umumnya, seperti terlalu kecil atau terlalu gemuk. Disamping itu ada model dan bahan baju tertentu yang lebih enak kalau dipakai dari hasil jahitan biasa, daripada dalam bentuk pakaian jadi yang diproduksi pabrik. Misalnya pakaian adat, bahan brukat, jas, kebaya, kain tenun dan lain-lain.

Pelatihan peningkatan ketrampilan kepada penjahit pakaian perlu diberikan agar mampu menghasilkan pakaian yang sesuai dengan keinginan pasar secara efisien dan efektif. Selain itu meningkatkan ketrampilan dalam mengobras dan membordir agar memiliki kemampuan bersaing dari sisi kualitas, model, variasi motif dan perpaduan warna pakaian yang di produksi, sehingga mampu menciptakan dan memiliki banyak jaringan pemasaran. Perlunya diberikan pelatihan yang memampukan penjahit pakaian menghitung total pendapatan penjualan dan total biaya sehingga mampu mengetahui berapa laba yang diperoleh per satu potong pakaian.

Diharapkan setelah pendampingan, para mitra menjadi lebih meningkat pengetahuannya, mampu mengaplikasikan pengetahuan tersebut dalam pekerjaan sehari-harinya dan menularkan pengetahuan tersebut kepada pelaku wirausaha penjahit pakaian yang lain. Dengan demikian semua penjahit pakaian akan lebih berkembang, menjadi semakin mandiri secara ekonomis, terjadi peningkatan pendapatan, penjahit pakaian menjadi lebih produktif serta semakin optimis dalam berwirausaha.
\end{abstract}

Kata kunci: Penjahit pakaian, Peningkatan Pendapatan

\section{PENDAHULUAN}

Menghadapi era persaingan yang semakin ketat, seseorang dituntut untuk memiliki semangat kewirausahaan yang tinggi sehingga dapat menjalankan usaha yang dijalaninya dengan baik. Dengan demikian kita harus dapat melihat peluangpeluang dan keinginan pasar dilihat dari segi kebutuhan serta nilai jual yang akan kita tawarkan kepada konsumen.

Dengan bertumbuhnya perusahaan, kebutuhan akan perencanaan semakin besar. Waktu tak dapat ditabung, waktu harus digunakan secara bijaksana. Sikap mental yang tepat terhadap pekerjaan sangatlah penting. Para wirausaha yang berhasil menikmati pekerjaan mereka dan berdedikasi total terhadap apa yang mereka lakukan.
Sikap mental positif mereka mengubah pekerjaan mereka menjadi pekerjaan yang menggairahkan, menarik dan memberi kepuasan.

Para wirausaha perlu mengelola waktunya dengan efektif, dan kunci penggunaan waktu yang terletak dalam manajemen yang lebih baik. Menjadi wirausaha berarti memiliki kemampuan menemukan dan mengevaluasi peluangpeluang, mengumpulkan sumber-sumber daya yang diperlukan dan bertindak untuk memperoleh keuntungan-keuntungan dari peluang-peluang itu. Wirausaha harus meluangkan sebagian besar waktunya untuk merencanakan kegiatan-kegiatan bisnis.

Berangkat dari hal-hal tersebut maka seorang wirausaha dituntut untuk bisa 
Berlianti. et al. Kemandirian Perempuan Melalui Keterampilan Menjahit

memanage atau mengendalikan pribadi sikapnya secara benar. Dalam menjalankan suatu usaha (wirausaha) seorang pelaku usaha harus memiliki :

1. Skill (kemampuan)

Seorang pelaku usaha harus memiliki skil (kemampuan) untuk berwirausaha karna tanpa skil (kemampuan) seorang pelaku usaha tidak akan mungkin bisa berwirausaha. Jadi skill (kemampuan) adalah modal utama yang harus dimiliki dalam berwirausaha.

2. Tekad (kemauan)

Apabila seorang pelaku usaha telah mempunyai skill (kemampuan) tapi tanpa ada tekad (kemauan yang kuat) untuk berwirausaha maka skill (kemampuan) berwirausaha itu akan sia-sia karena tidak dapat tersalurkan. Jadi pada dasarnya skill dan tekad itu harus dimiliki oleh seorang pelaku wirausaha

3. Modal

Modal merupakan aspek yang sangat menunjag dalam hal memulai dan menjalankan suatu usaha disamping mempunyai skill dan tekad.

4. Target dan Tujuan

Seorang pelaku usaha apabila ingin menjalankan suatu usaha maka harus bisa menentukan targer dan tujuan pemasarannya. Karena apabila target dan tujuan tidak direncanakan maka usaha yang dijalankan tidak mungkin dapat bertahan lama.

5. Tempat

Tempat berwirausaha merupakan aspek yang harus dimiliki bila ingin menjalankan wirausaha. Karena tempat juga sangat menunjang dalam hal wirausaha dan bisa menjadikan suatu bahan pertimbangan oleh konsumen mengenai wirausaha yang sedang dijalankan.

Dewasa ini, menjalankan wirausaha jasa menjahit pakaian masih menjanjikan. Meski sekarang sudah banyak produksi pakaian jadi, tetapi jasa jahitan tetap dibutuhkan konsumen. Karena ada beberapa risiko pembelian baju jadi yang biasanya diterima oleh pembeli.

Pakaian jadi biasanya dibuat dengan ukuran standar (S, M, L, dan XL). Meski model dan bahannya cukup bervariasi dan harganya pun lebih murah dibandingkan memakai jasa penjahit, tetapi tidak semua pakaian jadi pas dikenakan oleh konsumen. Terutama bagi orang-orang memiliki postur tubuh berbeda dengan standar orang pada umumnya, seperti terlalu kecil atau terlalu gemuk. Jasa jahitan akan tetap diburu oleh orang seperti ini.

Disamping itu ada model dan bahan baju tertentu yang lebih enak kalau dipakai dari hasil jahitan biasa, daripada dalam bentuk pakaian jadi yang diproduksi pabrik. Misalnya pakaian adat, bahan brukat, jas, kebaya, kain tenun dan lain-lain.

Mitra pengabdian ini adalah kaum perempuan di Kelurahan Sidorame Timur Kecamatan Medan Perjuangan Kota Medan yang membuka usaha jasa menjahit pakaian. Mitra sebenarnya mengkhususkan jasa menjahit pakaian kebaya, tetapi ada kalanya menerima jahitan pakaian lainnya seperti rok, baju, celana dan pakaian lainnya. Mereka masih memiliki alat yang terbatas, hanya mesin jahit. Untuk mengobras dan membordir masih harus mengupahkannya ke toko lain, sehingga membutuhkan waktu produksi yang lebih lama. Hal ini menjadikan mereka kurang efisien dalam bekerja. Disamping itu kesempatan untuk memperoleh untung yang lebih besar menjadi hilang.

\section{Permasalahan Mitra}

a. Rendahnya kapasitas perempuan penjahit pakaian dalam memahami persoalan-persoalan yang mereka hadapi.

b. Rendahnya keterampilan mitra dalam menjahit pakaian sehingga kurang mampu bersaing dari sisi kualitas, model, variasi motif dan perpaduan warna. 
c. Minimnya peralatan yang dimiliki mitra membuat hilangnya kesempatan memperoleh pendapatan yang lebih tinggi.

d. Rendahnya pengetahuan perempuan penjahit pakaian dalam memproduksi secara efektif dan efisien melalui perhitungan laba dan analisis biaya yang lebih baik, sehingga mampu meningkatkan pendapatan perempuan penjahit pakaian.

\section{SOLUSI DAN TARGET LUARAN}

\section{Solusi yang Ditawarkan}

Untuk meningkatkan daya saing wiausaha jasa menjahit pakaian, maka dirasa perlu melakukan pengabdian kepada perempuan penjahit pakaian dengan cara :

1. Ceramah dan diskusi, untuk mengetahui lebih jelas permasalahan dasar penjahit pakaian, sehingga bisa diberikan solusi masalah.

2. Mengadakan sosialisasi arti penting wirausaha jasa menjahit pakaian. Membuat perempuan di Kota Medan menjadi mandiri secara ekonomis. Meyakinkan mereka bahwa usaha jasa menjahit pakaian tetap akan diminati bila diproduksi sesuai dengan selera pasar dan dengan proses produksi yang efektif dan efisien.

3. Melaksanakan pelatihan dengan mengundang pakar obras dan bordir agar memiliki kemampuan memproduksi pakaian atau menjahit pakaian yang berkualitas baik dalam model, variasi motif dan juga perpaduan warna. Pemberian mesin pendukung diyakini membuat pelatihan akan lebih berhasil.

4. Melatih penjahit pakaian agar mampu memproduksi secara efektif dan efisien melalui perhitungan laba dan analisis biaya yang lebih baik, sehingga mampu meningkatkan pendapatan perempuan penjahit pakaian.

\section{Target luaran}

Luaran yang dihasilkan setelah selesainya kegiatan pengabdian pada masyarakat ini adalah :

1. Meningkatnya kapasitas mitra perempuan penjahit pakaian sehingga mampu memahami persoalan-persoalan yang mereka hadapi.

2. Meningkatnya pengetahuan dan keterampilan perempuan penjahit pakaian dalam mengobras dan membordir juga mampu menembus pasar yang lebih luas.

3. Meningkatnya keterampilan mitra dalam memproduksi pakaian sehingga mampu bersaing dari sisi kualitas, model, variasi motif dan perpaduan warna.

4. Menambah kemampuan dan skill para penjahit pakaian dalam menghitung total pendapatan, mengetahui faktor-faktor yang menentukan besarnya pendapatan penjualan. Mampu menghitung total biaya dan mengetahui cara untuk meminimalkan biaya produksi serta memampukan penjahit pakaian menghitung keuntungan per satu potong pakaian dan total keuntungan per bulan. 


\section{METODE PELAKSANAAN}

Metode pendekatan yang dilakukan selama melakukan pengabdian kepada mitra adalah dengan cara melakukan ceramah, sosialisasi, pelatihan, bimbingan dan pendampingan terhadap penjahit pakaian yang menjadi mitra. Pengukuran perubahan terhadap perilaku mitra dapat dilihat dari perilaku mitra yang berubah menjadi terbiasa dan mampu menghasilkan pakaian dengan cara yang efisien dan dengan kualitas yang bagus, dan motif yang sesuai dengan selera pasar, tetapi tetap berpegang pada budaya.

Mitra menjadi mengetahui teknik melakukan kegiatan produksi yang efektif dan efisien. Melalui kegiatan pengabdian ini mitra juga diharapkan semakin memiliki mental kewirausahaan serta mampu meningkatkan penjualannya dan jaringannya setelah diberikan pelatihan.

\section{Rencana Kegiatan}

Rencana kegiatan yang akan dilakukan untuk pemecahan masalah adalah dengan tahapan sebagai berikut :

\section{Sosialisasi}

Sosialisasi dilakukan kepada perempuan penjahit pakaian di Kota Medan. Materi sosialisasi adalah makna wirausaha jasa menjahit pakaian dapat meningkatkan pendapatan dan kesejahteraan masyarakat Medan.

2. Ceramah dan diskusi

Setelah kegiatan sosialisasi dilakukan tim pengabdian akan melakukan ceramah dan diskusi tentang rencana kegiatan. Berdasarkan ceramah dan diskusi ini tim pengabdian akan dapat mengetahui ketertarikan masyarakat terhadap kegiatan pengabdian. Selain itu dapat membangun motivasi tinggi untuk meningkatkan keterampilan.

3. Rekrutmen

Rekrutmen adalah bentuk pernyataan selain mitra yang bersedia untuk mengikuti kegiatan pengabdian. Penjahit pakaian yang bersedia selanjutnya dibimbing untuk mengikuti jadwal kegiatan pengabdian. Kegiatan rekrutmen ini bersifat sukarela tanpa ada paksaan ataupun tekanan dari siapapun.

4. Pelatihan Menjahit, Mengobras dan Membordir

Pelatihan dilakukan dengan mengundang orang yang memang sudah diakui keahliannya. Dalam pelatihan ini maka tim pengabdian akan memfasillitasi dan menyediakan semua bahan-bahan dan peralatan yang diperlukan dalam pembuatan pakaian tersebut. Pelatihan ini diharapkan akan meningkatkan keterampilan para mitra sehingga hampir sama dengan keterampilan tutornya.

5. Evaluasi

Evaluasi akan dilakukan selama pelaksanaan kegiatan pengabdian di Medan yang meliputi pengamatan keterampilan dalam menjahit, mengobras dan membordir pakaian. Selain itu juga evaluasi akan dilakukan 
meskipun kegiatan pelatihan sudah selesai, yaitu dengan bertelepon menanyakan kemajuan wirausaha jasa menjahit pakaian juga dengan mengunjungi kembali mitra menanyakan keuntungan dan hambatan yang dijumpai setelah kegiatan pelatihan selesai dilakukan.

\section{Kontribusi Partisipasi Mitra}

Dalam pelaksanaan pengabdian ini mitra pengabdian diharapkan memberikan kontribusi sebagai berikut :

1. Mitra bersedia mengikuti segala bentuk pelatihan dan berniat untuk merubah cara kerja menjadi lebih efisien dan efektif.

2. Mitra bersedia juga mengikuti pelatihan para penjahit pakaian dalam menghitung total pendapatan, mengetahui faktorfaktor yang menentukan besarnya pendapatan penjualan.

Mitra mampu menghitung total biaya dan mengetahui cara untuk meminimalkan biaya produksi serta mampu menghitung keuntungan per satu potong pakaian dan total keuntungan per bulan.

3. Mitra bersedia dan diteguhkan untuk membangun karakter wirausaha agar mengubah pola kerja, sehingga pekerjaan menjahit pakaian dapat diselesaikan tepat waktu sesuai dengan yang sudah disepakati.

\section{HASIL DAN LUARAN YANG DICAPAI}

Pengabdian diawali dengan kegiatan diskusi kelompok yang membahas permasalahan-permasalahan mitra. Tujuan diskusi dilakukan untuk mencari dan mengenali permasalahan yang dialami mitra pengabdian sekaligus untuk merumuskan metode

Tindak lanjut dari diskusi yang telah dilakukan adalah meningkatkan pengetahuan mitra mengenai masalah manajemen usaha, perhitungan harga pokok produksi dan pelatihan peningkatan ketrampilan. Permasalahan-permasalahan tersebut yang diyakini telah membuat operasional usaha mitra berjalan kurang efektif.

Kegiatan penyuluhan disepakati dilaksanakan di lokasi mitra. Metode penyuluhan dilakukan dengan metode ceramah kepada semua anggota kelompok mitra yang dilakukan secara berkelompok. Selanjutnya dilakukan pemberian hibah berupa mesin-mesin penunjang usaha mitra, serta bahan dan peralatan penunjang lainnya.

Peningkatan ketrampilan mitra dalam menjahit, bordir dan obras dilakukan dengan mendatangkan pelatih. Selama dua bulan 2 kali dalam seminggu pelatihan untuk meningkatkan ketrampilan ini dilakukan. Mengenai jadwal dan tempat pelatihan diserahkan kepada kesepakatan antara mitra dengan pelatih yang diundang. Hal ini bertujuan agar pelatihan dapat berjalan lebih efektif dan bermanfaat maksimal. 
Pelatihan yang diberikan nyata sangat efektif jika dilakukan dengan sekaligus menggunakan mesin atau peralatan penunjang yang dibutuhkan. Dalam hal ini pelatihan menjahit, bordir dan obras terlihat dapat dengan mudah dicerna dan dilaksanakan oleh mitra pengabdian. Hasil jahitannya kelihatan sudah lebih rapi, mengobras kain sudah bisa dilakukan sendiri tidak harus mengupahkannya lagi ke orang lain.

\section{HASIL KEGIATAN}

Pelatihan yang diberikan nyata sangat efektif jika dilakukan dengan sekaligus menggunakan mesin atau peralatan penunjang yang dibutuhkan. Dalam hal ini pelatihan menjahit, bordir dan obras terlihat dapat dengan mudah dicerna dan dilaksanakan oleh mitra pengabdian. Hasil jahitannya kelihatan sudah lebih rapi, mengobras kain sudah bisa dilakukan sendiri tidak harus mengupahkannya lagi ke orang lain.

Ketrampilan membordir pakaian nampaknya masih harus banyak latihan, karena hasilnya kelihatannya belum cukup rapi. Namun demikian mitra pengabdian telah berani untuk menerima jasa pembordiran yang akan dikerjakan secara perlahan-lahan dan lebih hati-hati dan penuh dengan tanggung jawab. Hal ini sangatlah membanggakan karena mitra menunjukkan jiwa wirausawan yang berani mengambil resiko sembari terus belajar dan berlatih.
Mitra pengabdian juga sudah memperoleh lonjakan order jasa menjahit pakaian. Kelihatan dari pembukuan mitra bahwa order jasa menjahit sudah penuh sampai ke bulan Januri tahun 2018. Bahkan mitra mengatakan sudah menolak beberapa konsumen yang ingin memakai jasa menjahit mitra abdi.

Lonjakan ini dipicu oleh dengan memanfaatkan sarana media sosial. Mitra abdi memposting di facebook hasil jahitannya yang terlihat sudah lebih rapi dan model yang lebih kekinian. Hal ini menumbuhkan konsumen-konsumen baru yang tidak dikenal sama sekali oleh mitra abdi.

Dengan peningkatan produksi dan produktivitas mitra abdi maka meningkat pulalah penghasilannya. Namun demikian mitra harus lebih disiplin dalam melakukan pencatatan pembukuannya. Karena terkadang masih dijumpai adanya biaya yang tidak atau lupa dicatatkan oleh mitra abdi. Sehingga perhitungan rugi laba dari usaha jasa menjahit yang dijalankan kurang atau tidak benar.

Kemampuan untuk mengetahui dan mendapatkan model-model terbaru kelihatannya sudah sangat dipahami oleh mitra abdi. Sehingga mitra pengabdian akan sudah dapat menjahit pakaian dengan modelmodel terbaru atau up to date sesuai dengan selera konsumen. 


\section{KESIMPULAN DAN SARAN}

Kesimpulan

1. Tumbuhnya minat perempuan untuk menjadi pelaku wirausaha menjahit.

2. Ketrampilan dan pengetahuan mitra pengabdian meningkat

3. Mitra pengabdian telah mampu menyusun pembukuan wirausaha menjahitnya.

4. Mitra pengabdian telah mampu mengembangkan wirausahanya, yang tadinya hanya melayani menjahit berkembang dengan usaha bordir dan obras.

5. Terjadi peningkatan pendapatan wirausaha mitra pengabdian.

Saran

1. Agar LPM USU dapat terus mendampingi mitra pengabdian hingga mitra benar-benar dapat menghasilkan kualitas jahitan yang sangat baik.

2. Pemasaran secara online dengan memanfaatkan media sosial nyata dapat meningkatkan jumlah konsumen, dengan demikian LPM USU dapat berperan untuk mendorongnya.

\section{UCAPABN TERIMA KASIH}

Artikel ini merupakan salah satu hasil dari Program Pengabdian kepada Masyarakat yang Dibiayai oleh BPPTN Universitas Sumatera Utara Sesuai dengan Surat Perjanjian Penugasan Pelaksanaan
Pengabdian kepada Masyarakat Program Mono Tahun (Dosen Muda) Tahun Anggaran 2017 Nomor:3224/UN5.2.3.2.1/PPM/2017, Tanggal 24 Juni 2017. Oleh karena itu, diucapkan terima kasih kepada Rektor Universitas Sumatera Utara dalam hal ini diwakili oleh Lembaga Pengabdian kepada Masyarakat Universitas Sumatera Utara atas dukungan dana dan fasilitas yang diberikan. Terima kasih juga kepada Mitra pada kegiatan pengabdian ini. Terima kasih juga kepada Mitra pada kegiatan pengabdian ini yang telah memberikan sarana dan prasarana sehingga kegiatan pengabdian ini dapat berjalan dengan dengan lancar.

\section{DAFTAR PUSTAKA}

Alma, Buchari. 2008. Manajemen Pemasaran dan Pemasaran Jasa. Penerbit Alfabeta, Bandung

Brigham, Eugene F and Joel F Houston. 2004. Fundamentals of Financial Management, $10 e$. International Student Edition. Thomson Learning

Cravens, David W. 2009. Strategic Marketing. Seventh Edition. Boston: Irwin McGraw-Hill

Ferdinand, Augusty. 2002. Marketing Strategy Making: Proses dan Agenda Penelitian. Journal Sains Pemasaran Indonesia. Vol 1, No.1, Mei, p.1-22

Hisrich \& Peters. 2002. Entrepreneurship, Fifth Edition. New York:McGrawHill Higher Education 
Kotler, Phillip. 2008. Marketing Management - The Millenium Edition. Prentice Hall

Salvatore, Dominick. 2005. Managerial Economics. Edisi Kelima. Jilid Pertama.Jakarta: Salemba Empat.

Salvatore, Dominick. 2005. Managerial Economics. Edisi Kelima. Jilid Kedua. Jakarta : Salemba Empat.

Suryana. 2006. Kewirausahaan Pedoman Praktis : Kiat dan Proses Menuju Sukses. Jakarta:Salemba Empat

Sutojo, Siswanto. 2003. Manajemen Penjualan yang Efektif. PT. Darma Mulia Pustaka

Van Horne, James and John M. Machowics, JR. 2001. Principle of Financial Management. Prentice Hall.

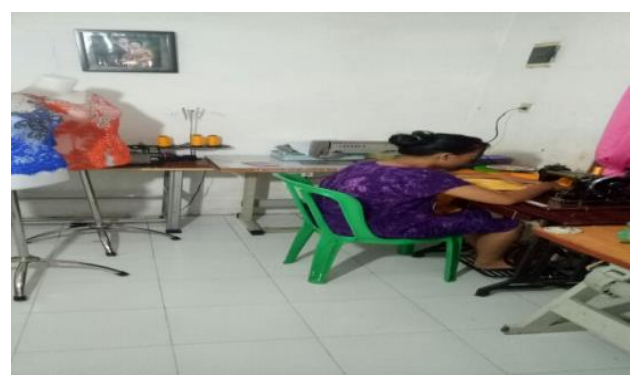

Gambar 1. Mitra pengabdian sedang menjahit

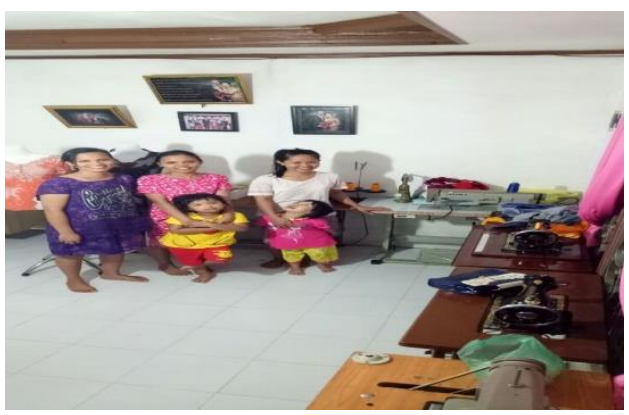

Gambar 2. Mitra berpose di depan mesin jahit yang dihibahkan

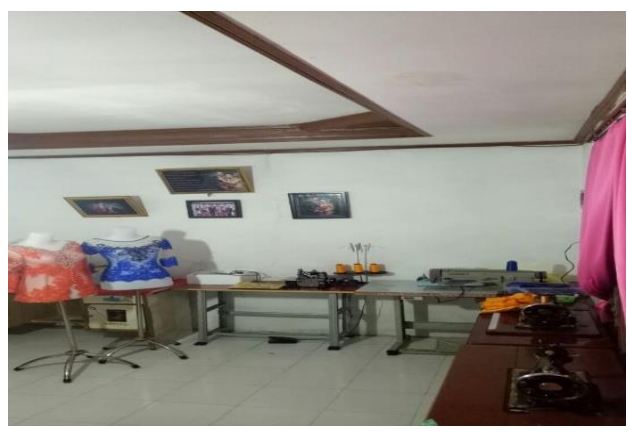

Gambar 3. Mesin/peralatan yang dihibahkan

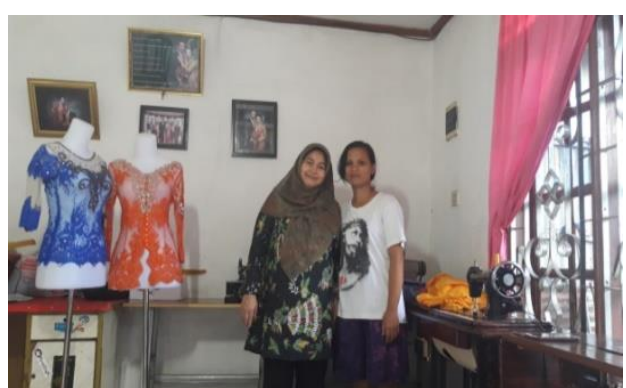

Gambar 4. Ketua tim pengabdian berpose dengan mitra pengabdian

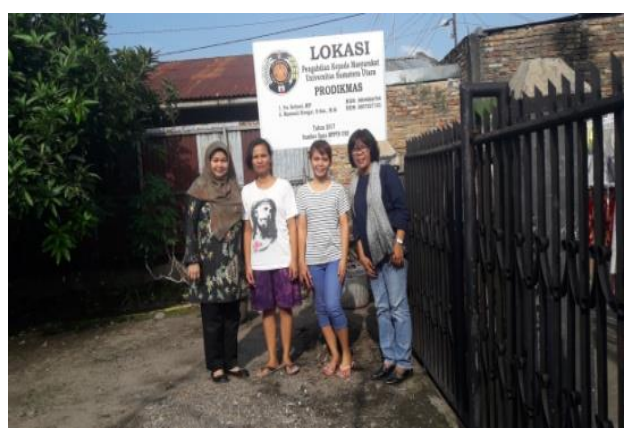

Gambar 5. Smile... anda ada di depan kamera

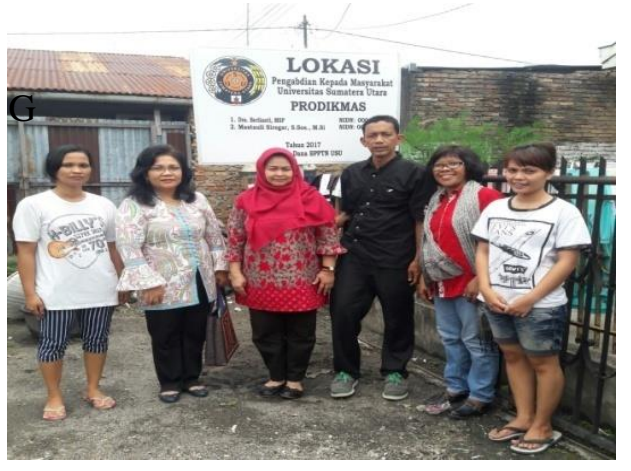

Gambar 6. Tim LPM USU melaksanakan MONEV 